\title{
Transformation of Plum with the Papaya Ringspot Virus Coat Protein Gene and Reaction of Transgenic Plants to Plum Pox Virus
}

\author{
Ralph Scorza \\ U.S. Department of Agriculture-Agricultural Research Service, Appalachian Fruit Research Station, 45
} Wiltshire Road, Kearneysville, WV 25430

\section{Laurene Levy}

U.S. Department of Agriculture Animal and Plant Health Inspection Service-Plant Protection Quarantine, Beltsville Agricultural Research Center-East Building 580, Beltsville, MD 20705

\section{Vern Damsteegt}

U.S. Department of Agriculture-Agricultural Research Service, Foreign Disease-Weed Science Research Unit, Frederick, MD 21702

Luz Marcel Yepes

Department of Plant Pathology, Cornell University, Geneva, NY 14456

\section{John Cordts}

U.S. Department of Agriculture-Agricultural Research Service, Appalachian Fruit Research Station, 45 Wiltshire Road, Kearneysville, WV 25430

\author{
Ahmed Hadidi \\ U.S. Department of Agriculture-Agricultural Research Service, National Germplasm Resources Laboratory, \\ Beltsville, MD 20705
}

\section{Jerry Slightom}

Molecular Biology Unit 7242, The Upjohn Company, Kalamazoo, MI 49007

\author{
Dennis Gonsalves \\ Department of Plant Pathology, Cornell University, Geneva, NY 14456
}

Additional index words. cross-protection, potyvirus, virus resistance

\begin{abstract}
Transgenic plum plants expressing the papaya ringspot virus (PRV) coat protein (CP) were produced by Agrobacterium-mediated transformation of hypocotyl slices. Hypocotyl slices were cocultivated with Agrobacterium tumefaciens strain C58/Z707 containing the plasmid pGA482GG/CPPRV-4. This plasmid carries the PRVCP gene construct and chimeric NPTII and GUS genes. Shoots were regenerated on Murashige and Skoog salts, vitamins, $2 \%$ sucrose, $2.5 \mu \mathrm{M}$ indolebutyric acid, $7.5 \mu \mathrm{M}$ thidiazuron, and appropriate antibiotics for selection. Integration of the foreign genes was verified through kanamycin resistance, GUS assays, polymerase chain reaction (PCR), and Southern blot analyses. Four transgenic clones were identified. Three were vegetatively propagated and graft-inoculated with plum pox virus (PPV)-infected budwood in a quarantine, containment greenhouse. PPV infection was evaluated over a 2- to 4-year period through visual symptoms, enzyme-linked immunosorbent assay, and reverse transcriptase PCR assays. While most plants showed signs of infection and systemic spread of PPV within 1-6 months, one plant appeared to delay the spread of virus and the appearance of disease symptoms. Virus spread was limited to basal portions of this plant up to 19 months postinoculation, but, after 32 months symptoms were evident and virus was detected throughout the plant. Our results suggest that heterologous protection with PRVCP, while having the potential to delay PPV symptoms and spread throughout plum plants, may not provide an adequate level of long-term resistance.
\end{abstract}

Plum pox virus (PPV), a member of the potyvirus group, is the causal agent of the plum pox (sharka) disease of stone fruits (Dunez and Sutic, 1988; Kegler et al., 1964). PPV was described for the first time in the early 1930s from Bulgaria (Atanasoff, 1932). It has progressively spread throughout most of Europe, the

Received for publication 1 Feb. 1995. Accepted for publication 16 May 199.5. This research was supported in part by a USAID-NARP grant administered by OICD/U.S Dept. of Agr. We acknowledge the advice and assistance of A.M. Callahan in the molecular analysis of transgenic plants. The cost of publishing this paper was defrayed in part by the payment of page charges. Under postal regulations, this paper therefore must be hereby marked advertisement solely to indicate this fact.
Mediterranean region, and England (Cropley, 1968; Refatti et al., 1985; Sutic and Pine, 1968). More recently, it was identified in Spain and Portugal (Llacer et al., 1986; Louro and Corvo, 1986). In 1988 it was identified in Egypt (Mazyad et al., 1992) and it has been identified in India and Chile (Roy and Smith, 1944). To date PPV has not been reported from other countries in Africa, Australia, Asia, or North America.

PPV is transmitted through grafting (Bauman, 1965; Christoff, 1958). It is also aphid transmitted in a nonpersistent manner (Kassanis and Sutic, 1965; Kunze and Krczal, 1971) and seed transmission has been reported from Eastern Europe (Nemeth, 1986). Symptoms of PPV infection include chlorotic leaf spots and 
blotches, mosaic patterns, and misshapen leaves. Spots and rings develop on young fruit and become necrotic and sunken during fruit ripening. Dark-colored spots form on the pit. Fruit drop prematurely, and fruit quality is reduced (Sutic and Pine, 1968; Trifonov, 1974). Death of infected trees-can occur upon coinfection with other viruses (Nemeth, 1986).

Cross protection has been used as a strategy to protect plants against infection by homologous or closely related viruses. The process was originally based on inoculation of plants with an attenuated virus strain in order to protect against a severe strain (McKinney, 1929). In the last 10 years, strategies for the protection of plants against virus diseases have been expanded to include transgenic plants expressing viral genes, which inhibit virus infection (Sanford and Johnston, 1985). Viral coat protein (CP) genes have been most commonly used. Since the initial report of CPmediated resistance against tobacco mosaic virus infection in transgenic tobacco (Abel et al., 1986), work with viruses such as alfalfa mosaic, cucumber mosaic, potato $\mathrm{X}$ and $\mathrm{Y}$. tobacco etch, tobacco mosaic, tobacco rattle, and tobacco streak have produced CP-mediated resistance of varying degrees in transgenic host plants (see review of Beachy et al., 1990). Recently, the PPVCP gene has been transferred into apricot (Laimer da Camara Machado et al., 1992) and plum (Scorza et al., 1994b).

While it has been shown that expression of $\mathrm{CP}$ can confer resistance to homologous viruses, heterologous resistance has also been reported in several potyvirus systems (Ling et al., 1991; Maiti et al., 1993; Namba et al., 1992; Stark and Beachy, 1989). PRVCP has been shown to protect transgenic tobacco plants against other potyviruses (tobacco etch, potato virus Y, and pepper mottle) (Ling et al., 1991). The finding that heterologous CP-mediated protection occurs among these potyviruses suggested the potential for using PRVCP to protect plants against PPV infection. We have previously shown that Agrobacterium tumefuciens can be used to transfer foreign DNA into the genome of $P$. domestica (Mante et al., 1991). Several years ago we developed plum plants transgenic for the PRVCP gene (Scorza et al., 1991) and now we report our results after these plants were inoculated with PPV and evaluated over a 2- to 4-year period for reaction to PPV infection.

\section{Materials and Methods}

\section{Plant material}

Seeds of the plum cultivar Stanley' and a breeding selection B70146 were collected and used fresh, or after storage at 4C for up to 1 month. Seeds, including endocarps, were removed from fruit before storage. Explant preparation before cocultivation was as described by Mante et al. (1991). GF305 peach (Cummins, 1991) was used as a PPV indicator. PPV-infected GF305 was used as an inoculum source to transfer PPV into plum by grafting.

\section{Agrobacterium strain and plasmid description}

Construction and use of the binary plasmid pGA482GG/ CPPRV-4 has been described (Fitch et al., 1990, 1992; Ling et al., 1991; Slightom, 1991). Agrobacterium tumefaciens strain C58/Z707, kindly supplied by A. Hepburn (Profile Diagnostics, New York), containing pGA482GG/CPPRV-4, was grown overnight at $28 \mathrm{C}$ in Luria broth with $50 \mathrm{mg} \cdot$ liter $^{-1}$ kanamycin $^{-}$ (kan) and $40 \mathrm{mg} \cdot$ liter $^{-1}$ gentamicin as selective antibiotics for the $\mathrm{Ti}$ plasmid and the binary cosmid, respectively. Bacterial cells were pelleted by centrifugation $(4000 \times g, 5 \mathrm{~min})$ and resuspended in $10 \mathrm{ml}$ of half-strength Murashige and Skoog (MS) (Murashige and Skoog, 1962) liquid medium containing $100 \mu \mathrm{M}$ acetosyringone.

\section{PPV strain}

The PPV strain used in this study was designated as 24830A. It was isolated from a European plum import accession from Romania and identified by H.E. Waterworth, U.S. Dept. of AgricultureAgricultural Research Service (USDA-ARS) National Germplasm Resources Laboratory, Beltsville, Md. This isolate produces typical chlorotic flecking and leaf distortion in GF305 indicator seedlings and typical symptoms in plum, including chlorotic rings, oakleaf pattern, and vein banding. Indicator plants inoculated with infected budwood did not indicate the presence of other viruses in the original PPV-infected accession from which our inoculum was obtained (H.E. Waterworth, personal communication). Isolate 24830A reacts positively with PPV antiserum to PPV-W (BioReba Ag, Basel, Switzerland), a strain of PPV from the Netherlands. PPV-24830A was graft inoculated from the original host plum onto GF305 peach seedlings to maintain the isolate for subsequent challenge inoculations. Work with this virus was carried out under strict quarantine conditions at the USDA-ARS Foreign Disease Weed Science Research Unit, Frederick, Md., as specified under Animal and Plant Health Inspection Service permit no. 9024281

\section{Regeneration and transformation of plum plants from hypocotyl slices}

Regeneration medium and plant culture and rooting media and conditions were those described by Mante et al. (1991). Briefly, media were MS salt-based. Indole-3-butyric acid (IBA) at $2.5 \mu \mathrm{M}$ and $7.5 \mu \mathrm{M}$ thidiazuron (TDZ) were used for shoot regeneration medium (SRM). IBA at $2.5 \mu \mathrm{M}$ was used for rooting medium (RM). Cocultivation was carried out by explanting hypocotyl slices onto agar-solidified $(0.8 \%)$ SRM containing $100 \mu \mathrm{M}$ acetosyringone and placing $10-20 \mathrm{ml}$ of the resuspended A. tumefaciens culture to completely cover each slice. Cocultivation was carried out for 48 $\mathrm{h}$ at $24 \mathrm{C}$. Following cocultivation the explants were washed three times in MS liquid medium containing $500 \mathrm{mg} \cdot \mathrm{liter}^{-1}$ carbenicillin $^{-1}$ and $200 \mathrm{mg} \cdot \mathrm{liter}^{-1}$ cefotaxime. Explants were then placed on agarsolidified SRM containing carbenicillin and cefotaxime in the same concentrations as the wash and cultured for 6-10 days. Explants were then cultured on SRM with carbenicillin and cefotaxime as above with $75 \mathrm{mg} \cdot \mathrm{liter}^{-1} \mathrm{kan}$. Regenerated shoots were subcultured onto fresh selective medium (SRM with antibiotics) every 3-4 weeks until they were confirmed to be transgenic.

\section{Confirmation of transformation}

P-GUS assays. Shoots that grew in the presence of $75 \mathrm{mg} \cdot \mathrm{liter}^{-1}$ kan were assayed for $\beta$-glucuronidase (GUS) activity. Leaf tissue cut from these shoots was incubated for 16 to $24 \mathrm{~h}$ in an X-Glut solution (Jefferson, 1987). To verify the absence of Agrobacterium on putative transformants, leaves were excised from in vitrogrown shoots and cultured for two weeks in liquid Luria broth on a rotating shaker at $26-27 \mathrm{C}$.

Polymerase chain reaction (PCR). PCR amplification was conducted on DNA isolated from leaves of transformed plum and tobacco (Nicotiana tabacum L.) clones. The tobacco plants were transformed to serve as positive controls for GUS and molecular assays of transformation with the vector used in this study. The tobacco transformation protocol was as described by Scorza et al. (1994a). Specific oligonucleotide primers at the 5' and 3 ' end of the PRVCP, GUS and NPTII genes were used to identify the presence of these genes in DNA isolated from different transgenic clones. The following primers were for the NPTII gene 5'-primer, 5'-CCCCTC-GGT-ATC-CAA-TTA-GAG-3', and 3'-primer, 5' CGGGGG-GTG-GGC-GAA-GAA-CTC-CAG-3'. Primers for the GUS gene were 5'-primer, 5'-GAT-CAG-CGT-TGG-TGG-GAA-AGC- 
GCG-3', and 3'-primer, 5'-CAC-CGA-AGT-TCA-TGC-CAGTCC-AGC-G-3'. Primers for the PRVCP were 5'-primer, 5'-CTGTGG-ATG-CTG-GTT-TGA-ATG-3'; 3'-primer, 5'-GGT-GAAACA-GGG-TCG-AGT-CAG-3'. PCR reactions were run with a kit (Perkin-Elmer Cetus, Norwalk, Conn.) following the conditions recommended by the manufacturer. After 35 amplification cycles, the PCR products were separated by agarose gel electrophoresis and stained with ethidium bromide.

Southern blot analysis. Actively growing leaves were collected from uninoculated transgenic clones growing in the greenhouse. DNA isolation followed the procedures of Scorza et al. (1995). The isolated DNA was digested with HindIII. A PCR-generated 1.1-kb nopaline synthase/neomycin phosphotransferase (NOS/NPTII) fragment was used as the probe (Scorza et al. 1995). This enzymeprobe combination would detect unique insertion events associated with the juncture of plant DNA and the right border of the plasmid (see plasmid map in Fitch et al., 1990).

\section{Propagation of transgenic plants}

Following the identification of individual transgenic shoots, each shoot was isolated, separately labelled, and multiplied through axillary shoot proliferation on MS-based medium containing $0.2 \mu \mathrm{M}$ IBA and $5 \mu \mathrm{M}$ N-6-benzyladenine (BA). These axillary shoots arising from distinct transgenic clones were separated, identified as propagules of their original transgenic clone, and rooted on RM containing 75 $\mathrm{mg} \cdot$ liter $^{-1} \mathrm{kan}$. They were subsequently acclimated to greenhouse conditions as previously described (Mante et al., 1989).

\section{Greenhouse conditions}

Plants grown in the greenhouse for inoculation studies were fertilized weekly with a dilute solution of Peters 20N-20P-20K (Grace Sierra Horticultural Products Co., Milpitas, Calif). Insects and mites were controlled as necessary using Resmethrin Pt1280 (Whitmire Res. Labs, Inc., St. Louis), Vendex 50 wp (Shell Chemical Co., Houston), Pentac Aquaflow (Sandoz Crop Protection Corp., Des Plaines, Ill.), and/or Safer soap (Safer Inc., Eden Prairie, Minn.). During natural short-day periods, a 16-h daylength was provided by supplemental lighting with high pressure sodium lamps. Light intensities ranged from $32 \mu \mathrm{mol} \cdot \mathrm{m}^{-2} \cdot \mathrm{s}^{-1}$ at bench level to $95 \mu \mathrm{mol} \cdot \mathrm{m}^{-2} \cdot \mathrm{s}^{-1}$ at the top of plants. Greenhouse temperatures ranged from 18-25C (night-day).

\section{Graft inoculation and evaluation of transgenic plants}

All graft inoculations with PPV were done at the USDA Foreign Disease-Weed Science Research Unit. Budwood was collected from PPV strain 24830A-infected GF305 peach. Budwood was selected based on the presence of characteristic leaf distortion and chlorotic flecking associated with PPV infection on GF305. Within 20 min of collecting budwood, buds were grafted into the main stem of each transgenic (clones ST1, EF1, and EF2) and untransformed control (UTC) plum plant, two buds/plant. Untransformed control plants were 'Stanley' plum, from which one of the transgenic seedling lines was produced; B70173, a sister seedling of the parental plum line B70146 from which three transgenic seedlings were produced; and B6915, a plum line more distantly related to B70146. These were growing on peach rootstock. Two inoculum buds/budstick were also grafted onto healthy GF305 plants, which were then evaluated for PPV symptoms to verify the PPV transmission potential of each budstick. Over about 15 months, nine ST1, nine EF1, three EF2, and nine UTC were inoculated. In many cases, the infected GF305 buds grew and produced shoots on the plum plants, confirming success of the graft union and probable virus transmission to the plum plant.

\section{Evaluation of PPV infection}

PPV infection was evaluated through visual rating of symptoms, through immunological assays, including double and triple antibody sandwich enzyme-linked immunosorbent assay (ELISA), through reverse transcriptase (RT)-PCR, and by a GF305 in planta indicator. The latter test was done as follows. In February 1992, buds from healthy GF305 seedlings were budded into previously PPV-inoculated plum plants, which included four ST1, four EF1, two EF2, and four NTC. One bud was placed above the PPVinfected bud graft and another on a major side branch. Through pruning, these newly inserted test buds were forced to grow. The GF305 in planta indicator for each plant was assayed for infection visually, by ELISA, and in some cases by RT-PCR. To verify that all plants in the study were transgenic, a leaf sample from each assayed branch from each plant (at least two branches per plant) was assayed for GUS activity as previously described. Transformed, uninoculated plants of clones ST1, EF1, and EF2 were used as negative controls for ELISA and RT-PCR detection of PPV.

\section{Verification of PPV infection-visual assays}

Plants were periodically monitored for visual symptoms of PPV infection. In late March 1992, 6 weeks after the final inoculations, all inoculated plants were evaluated for PPV symptoms on a whole-plant basis. These samples were evaluated by rating visual symptoms on a scale of $0-3$, with $0=$ a complete absence of visual symptoms and $3=$ severe symptoms including strong vein clearing, leaf distortion, chlorotic ring lesions, and/or mosaic. Ratings of 1 and $2=$ intermediate levels of symptoms between the extremes of 0 and 3 .

\section{Verification of PPV infection-immunological assays}

Double antibody sandwich (DAS) ELBA. Inoculated plants and controls were evaluated for infection by DAS ELISA in March, June, and September 1991, January and December 1992, October 1993, and October 1994. Only some plants that exhibited PPV symptoms and were highly positive in one or more ELISA assays by June 1992 were repeatedly assayed after that date. Leaves from tested plants were randomly sampled throughout each plant or in cases where individual branches were compared leaf samples were separated. All samples were stored frozen at -20C until use (not more than 1 month), at which time they were pulverized in liquid nitrogen and homogenized with extraction buffer PBST-M (phosphate buffered saline plus Tween 20, plus nonfat dried milk, $\mathrm{pH} 7.4$ ) in a 1:5 w/v ratio. ELISA procedures were as described (Clark and Adams, 1977) using apolyclonal antiserum to PPV-W (BioReba Ag). Sample volumes of $100 \mu \mathrm{l} /$ well in paired wells of Immulon 3 microtiter plates (Dynatech, Chantilly, Va.) were used. Reactions were visualized spectrophotometrically at $405 \mathrm{~nm}$. Positive reactions were the mean of two wells per plate at a value of at least $2.5 \times$ healthy plant (transgenic non-PPV challenged) control mean values.

Triple antibody sandwich (TAS) ELISA. Inoculated plants and uninoculated controls were evaluated for infection by TAS ELISA in June 1992. The fact that a single plant could consist of branches showing both strong and mild symptoms led us to select two main branches per plant for TAS ELISA assays. If a plant had one branch with severe symptoms and one with mild symptoms, these two were preferentially selected. Furthermore, since symptom severity appeared to be positively related to leaf age or position in many plants, leaf samples from the two sampled branches per plant were further subdivided into two classes: apical, immature leaves, and basal, mature leaves. All TAS ELISA volumes were $150 \mu \mathrm{l} /$ well in Maxisorp microplates (A/S Nunc, Kamstrup, 
Denmark). The procedures were as described (Jordan and Hammond, 1991) with minor modifications. Polyclonal antiserum to PPV-W (BioReba Ag) was used as a capturing antibody. An intermediate unlabeled potato virus $\mathrm{Y}$ group-specific monoclonal antibody (AgDia, Elkhart, Ind.) was added followed by a detecting alkaline phosphatase conjugated goat-antimouse antibody (Kirkegaard and Perry, Gaithersburg, Md.). Results were visualized at $405 \mathrm{~nm}$. Positives were the mean of two wells per plate having a value of at least $2.5 \times$ healthy transgenic (non-PPV challenged) control mean values.

\section{Verification of PPV infection-RT PCR}

In December 1992 and October 1994 selected plants were tested for the presence of PPV 3' noncoding region (NCR) through RT-PCR as described below.

Nucleic acid extraction and purification. Total nucleic acids (TNA) were extracted from leaf tissue as described by Yang et al. (1992) Briefly, $1 \mathrm{~g}$ of tissue was ground in liquid nitrogen and extracted with $5 \mathrm{ml}$ of buffer consisting of $0.1 \mathrm{M}$ glycine-sodium hydroxide, $\mathrm{pH} 9.0,50 \mathrm{~mm}$ sodium citrate, $1 \mathrm{~mm}$ disodium ethylenediamine tetraacetic acid (EDTA), 2\% sodium dodecyl sulfate (SDS), and 1\% sodium lauryl sarcosine. Samples were further extracted with the addition of an equal volume of Tris- $\mathrm{HCl}$ buffered phenol, pH 7.6-8.0 containing 0.1\% 8-hydroxyquinoline and 0.2\% 2-mercaptoethanol, and a subsequent addition of an equal volume of chloroform. Nucleic acid preparations were further purified using RNase-free ELUTIP-R minicolumns (Schleicher and Schuell, Keene, N.H.) according to the manufacturer.

Virus cDNA synthesis. One microgram of TNA was added to 1 $\mu \mathrm{g}$ of the PPV-specific primer (synthesized by Synthecell, Rockville, Md.) (Hadidi and Levy, 1994; Levy and Hadidi, 1994). The primer-TNA mixture was then added to $6 \mu \mathrm{l}$ of $5 \times$ first strand cDNA buffer (250 mM Tris-HCl, $\mathrm{pH} 8.3,375 \mathrm{~mm} \mathrm{KCl,} 15 \mathrm{~mm}$ dithiothreitol) and deionized water to a final vol of $30 \mu \mathrm{l}$. TNAprimer mixture was denatured by heating at 100C for $5 \mathrm{~min}$, chilled on ice for $2 \mathrm{~min}$, and annealed at room temperature for $1 \mathrm{~h}$. The following reagents were then added to the reaction mixture: $4 \mu \mathrm{l} 5 \mathrm{x}$ first strand cDNA buffer, $5 \mu \mathrm{l} 300 \mu \mathrm{M}$ 2-mercaptoethanol, $2.5 \mu \mathrm{l} 10$ mM dNPT (2.5 mM each of dATP, dGTP, dTTP, dCTP), $1 \mu \mathrm{l}$ RNasin (40 units/ $\mu$ l, Promega Corp., Madison, Wis.), $1.0 \mu \mathrm{l}$ of cloned Maloney murine leukemia virus reverse transcriptase (200 units/ $\mu$, GIBCO BRL Life Technologies, Inc., Gaithersburg, Md.), and deionized water to a vol of $50 \mu 1$. The reaction was incubated at $42 \mathrm{C}$ for $1 \mathrm{~h}$.

PCR amplifiation. PCR reactions contained $5 \mu 1$ of the PPV cDNA reaction added to a $45 \mu \mathrm{l}$ reaction mixture containing $1 \times$ PCR buffer (10 mM Tris-HCl, pH 8.3, $50 \mathrm{~mm} \mathrm{KCl,} 1.5 \mathrm{~mm} \mathrm{MgCl}$, and $0.01 \%$ gelatin), $200 \mu \mathrm{M}$ dNTP (dGTP, dATP, dTTP, and $\mathrm{dCTP}), 0.12 \mu \mathrm{M}$ each of PPV-specific primers, 2.5 units of Taq DNA polymerase (Promega Corp., Madison, Wis.) and deionized water. Cycling parameters were $30 \mathrm{sec}$ at $94 \mathrm{C}, 30 \mathrm{sec}$ at $62 \mathrm{C}$, and $45 \mathrm{sec}$ at $72 \mathrm{C}$ for 30 cycles with the final extension at $72 \mathrm{C}$ for $7 \mathrm{~min}$ in a DNA thermal cycler (Perkin-Elmer Corp., Norwalk, Conn.). The RT-PCR products were analyzed by agarose electrophoresis [1.2\% agarose in TBE buffer (Tris/boric acid/EDTA, $\mathrm{pH}$ 8.0)] and stained with ethidium bromide.

\section{Results}

Transformation of plum hypocotyl slices and identification of transgenic plants. One putative transformant was obtained from a total of about 50 hypocotyl slices of 'Stanley' seeds. From a total of about 100 hypocotyls from seeds of selection B70146, three

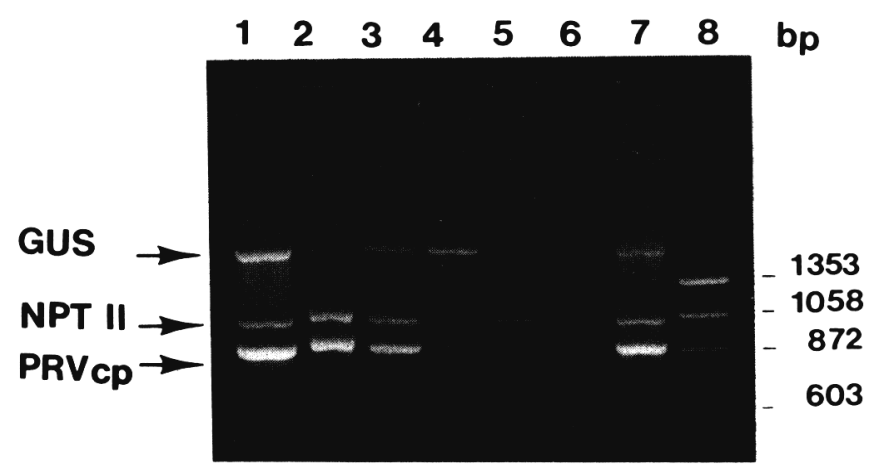

Fig. 1. PCR amplification was used to determine the presence of the PRVCP, GUS, and NPTII genes. Each reaction was run adding oligonucleotides for the three genes simultaneously. Samples were loaded as follows: lane 1, transgenic tobacco clone PRV-A, lanes 2-5, transgenic plum clones H1, ST1, EF2, and EF1, respectively; lane 6, negative control (nontransformed 'Stanley' plum); lane 7, positive control (plasmid pGA482GGCPPRV-4 containing the three genes; and lane 8, molecular size standard $\phi$ X174 RF DNA / Hae fragments.

putative transformants were selected based upon survival and growth on $75 \mathrm{mg} \cdot \mathrm{liter}^{-1} \mathrm{kan}$. Leaf pieces from these clones, when incubated in X-Gluc, displayed the blue staining indicative of GUS expression. Tests for residual Agrobacterium growth on putative transformants were negative. PCR analysis indicated that the four plum clones and the transgenic tobacco control, included to verify molecular weights of the transgenes post-insertion, contained the

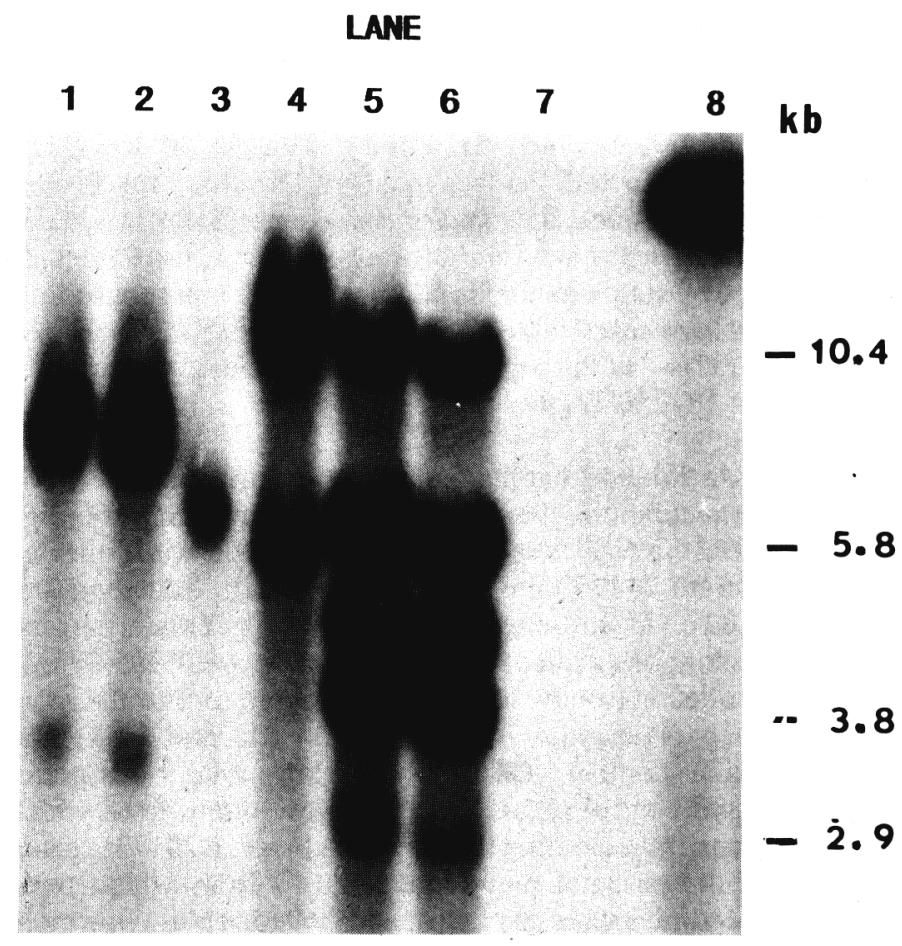

Fig. 2. Southern blot analysis to determine the presence of the pGA482GG/ CPPRV4 gene insert in transgenic plum plants. Plum DNA was digested with HindIII. The probe was a PCR-generated 1.1-kb NOS/NPTII fragment (see Scorza et al., 1995). Lane 1, transgenic plum clone EF1 plant 24 (EF1-24) PPVsymptom-expressing branch, lane 2, EF1-24 branch without PPV symptoms; lane 3, transgenic plumclone $\mathrm{H} 1$ plant 16; lane 4, transgenic plum clone EF2 plant 11; lane 5, transgenic plum clone ST1 plant 1 (ST1-1); lane 6, ST1-15; lane 7, untransformed control plum; and lane 8, pGA482GG/CPPRV-4 plasmid control. 
Table 1.. Evaluation of PPV infection of PRVCP transgenic plum plants and nontransformed controls (NTCs) inoculated in November 1990, February 1991, May 1991, or February 1992.

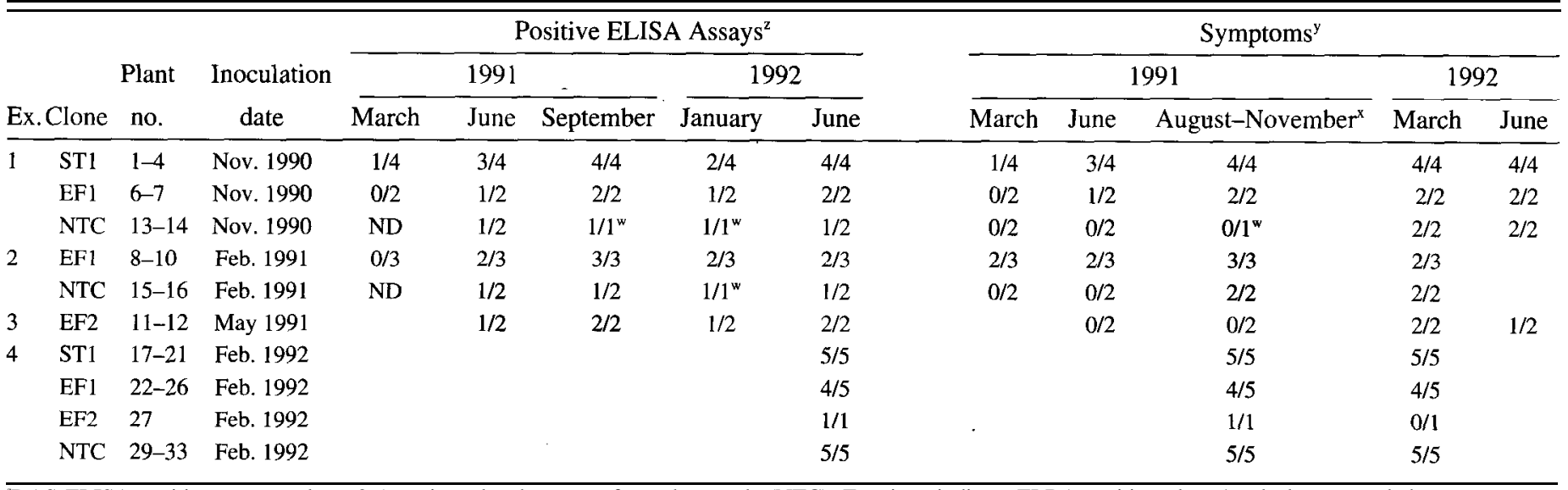

${ }^{2}$ DAS ELISA positives were at least $2.5 \times$ uninoculated nontransformed controls (NTC). Fractions indicate ELBA-positive plants/total plants sampled.

${ }^{y}$ Fractions indicate the number of plants with symptoms/total plants sampled.

'Combined data from evaluations undertaken between late August through mid-November 1991.

"Due to insufficient growth, leaves from one plant were not available for sampling.

GUS, NPTII, and PRVCP gene inserts (Fig. 1), Clone H1 was not used further in the studies reported here because it grew slowly and few propagated plants were available for testing. Figure 2 shows a Southern blot of DNAs isolated from the four transgenic clones. The differences in molecular weight of the bands indicate different insertion events, because one Hind111 restriction enzyme cut would occur within the T-DNA and the other in associated plant DNA depending upon where in the genome the insertion was located. This blot indicates that clone EF- 1 contains one or two copies of the insert (the lighter band at about $3.5 \mathrm{~kb}$ may be a result of DNA degradation), EF-2 has two copies, ST-1, four to five copies and $\mathrm{H} 1$, one copy of the transgene. In contrast, DNA from a control non-transformed plant (lane 7) did not hybridize with the NOS/ NPTII probe.

Evaluation of inoculated plants. Since PPV is known to be unevenly distributed in fruit trees (Adams, 1978; Dunez and Sutic, 1988), budwood of infected GF305 plants that were used as inoculum sources were checked for PPV infection first, by symptomatology, and then by graft-inoculating selected buds to healthy GF305 seedlings. All of the inoculated GF305 seedlings became infected, indicating that virus was present in the shoots that were a source of inoculum for the transgenic plums. Table 1 summarizes the results of the four inoculation experiments done for this study. Although only one of a total of six plants of transgenic lines ST1 and EF1 that were inoculated in November 1990 had symptoms in March 1991, four of the six and one of two nontransformed controls (NTCs) had symptoms by June 1991. All seven sampled plants showed symptoms by September 1991. These symptoms included mild to severe chlorosis and ringspot patterns. DAS ELISA performed in 1991 on these plants supported observations made when evaluating symptom development (Table 1). The number of ELISA positive plants and the number of plants showing symptoms were the same for all transgenic clones except on the ELISA tests conductedduring the winter (January 1992). In this test over $40 \%$ of the plants that were previously ELISA positive were found to be negative (Table 1). Symptoms were delayed on the two NTCs and only one of them was positive by ELISA even though symptoms developed in both. The second group of plants inoculated were three of transgenic clone EF1 and two NTCs inoculated in February 1991. The three transgenic plants showed symptoms by June 1991 and by March 1992 all five plants (transgenics and controls) were symptomatic. The first positive ELISA tests were obtained in June 1991 for the transgenic plants. Again, in the winter (January 1992), one previously ELISA positive plant was negative. The NTCs for this test as well as those for the first test grew poorly, and it was difficult to assay symptoms or sample the few leaves on these plants for ELISA assays. It is possible that poor growth was in itself a symptom of PPV infection, but this could not be verified.

In a third experiment, two cloned plants of line EF2 were inoculated in May 1991. Both were ELISA positive in September 1991 and symptomatic by March 1992 (Table 1). Like the previous observations, only one plant was ELISA positive in the assay done in January 1992.

To better standardize the inoculation times of the different transgenic lines, a fourth set of inoculations was done where five cloned plants each of lines ST1 and EF1, one plant of EF2 and five NTC were inoculated in February 1992. Results from this experiment were similar to the previous experiments. Most plants were symptomatic by the end of March (six weeks after inoculation) and ELISA positive. One plant, EF2 \#27, was only mildly symptomatic in March 1992 and did not show symptoms in June 1992, although the positive ELISA reaction in June confirmed that it was infected. Another plant, EF1 \#24, stood out as not being symptomatic in March, June or December (December symptom data not presented), nor did it test positive by ELISA during the 10 months from February to December 1992.

While Table 1 summarizes data from all experiments, it does not provide detailed data that were taken for each plant on symptoms on different branches, and analysis of selected leaves of branches for degree of symptom expression, ELISA, and RT-PCR. Since the general trends for symptoms, ELISA, and RT-PCR were similar among inoculated plants, detailed data are provided for only seven typical plants and for EF1 plant \#24, which had delayed symptom expression and a delay in positive ELISA and RT-PCR reactions (Table 2). Most of the plants evaluated on an individual branch basis displayed symptoms of PPV infection in both sampled branches (Table 2).

The level of symptom expression was generally supported by DAS and TAS ELISA data with more severe symptoms reflected in higher ELISA absorbance values. RT-PCR successfully detected the PPV 3' NCR in symptom-expressing and symptomless 
Table 2. Detailed analysis of PPV infection of PRVCP transgenic plums and nontransformed control (NTC) plums.

\begin{tabular}{|c|c|c|c|c|c|c|c|c|c|c|c|}
\hline \multirow[b]{2}{*}{ Clone } & \multirow[b]{2}{*}{$\begin{array}{c}\text { Plant } \\
\text { no. }\end{array}$} & \multirow[b]{2}{*}{$\begin{array}{c}\text { Inoculation } \\
\text { date }\end{array}$} & \multirow[b]{2}{*}{ Branch } & \multirow[b]{2}{*}{ Position ${ }^{2}$} & \multicolumn{3}{|c|}{ Symptoms ${ }^{\mathrm{y}}$} & \multicolumn{2}{|c|}{ ELISA $^{\mathrm{x}}$} & \multicolumn{2}{|c|}{ RTPCR } \\
\hline & & & & & $\begin{array}{l}\text { June } \\
1992\end{array}$ & $\begin{array}{l}\text { June } \\
1993\end{array}$ & $\begin{array}{c}\text { October } \\
1994\end{array}$ & $\begin{array}{l}\text { June } \\
1992 \\
\end{array}$ & $\begin{array}{c}\text { October } \\
1994^{w}\end{array}$ & $\begin{array}{c}\text { December } \\
1992 \\
\end{array}$ & $\begin{array}{c}\text { October } \\
1994^{\mathrm{w}} \\
\end{array}$ \\
\hline \multirow[t]{4}{*}{ ST1 } & 4 & $11 / 90$ & 1 & $\mathrm{~A}$ & 2 & & 3 & - & +++ & (v) & ++ \\
\hline & & & & B & 2 & 3 & + & & & & \\
\hline & & & 2 & A & 2 & 3 & + & +++ & & & \\
\hline & & & & B & 3 & 3 & + & & & & \\
\hline \multirow[t]{4}{*}{ EF1 } & 8 & $2 / 91$ & 1 & A & 3 & Dead & $3^{\mathrm{u}}$ & +++ & $+++^{\mathrm{u}}$ & $++^{\mathrm{u}}$ & \\
\hline & & & & B & 3 & Dead & $3^{u}$ & ++ & & & \\
\hline & & & 2 & A & 3 & $\mathrm{NG}^{\mathrm{t}}$ & 3 & ++++++ & & & \\
\hline & & & & $\mathrm{B}$ & 3 & 3 & 3 & + & & & \\
\hline \multirow[t]{5}{*}{ EF1 } & 23 & $2 / 92$ & 1 & A & 0 & Dead & $3^{\mathrm{u}}$ & - & & $++^{u}$ & \\
\hline & & & & B & 0 & Dead & $3^{u}$ & - & - & & \\
\hline & & & 2 & A & 2 & 3 & 3 & ++ & +++ & ++ & \\
\hline & & & & $\mathbf{M}$ & 3 & 3 & 3 & ++ & ++ & & \\
\hline & & & & B & 0 & 3 & 3 & - & & & \\
\hline \multirow[t]{4}{*}{$\mathrm{EF} 1$} & 24 & $2 / 92$ & 1 & $\mathrm{~A}$ & 0 & 0 & 0 & - & +++ & + & ++ \\
\hline & & & & B & 0 & 2 & 2 & - & & + & \\
\hline & & & 2 & A & 0 & 0 & 0 & - & +++ & + & ++ \\
\hline & & & & $\mathrm{B}$ & 0 & 1 & 2 & - & + & & \\
\hline EF1 & 24 & & GF305 & & 3 & 3 & 3 & +++ & ++ & & \\
\hline \multirow[t]{4}{*}{$\mathrm{EF} 2$} & 11 & $5 / 91$ & 1 & A & 0 & Dead & $3^{u}$ & + & $+++^{u}$ & & \\
\hline & & & & B & 0 & 1 & 3 & + & & & \\
\hline & & & 2 & A & 0 & $N G^{t}$ & 3 & + & +++ & & ++ \\
\hline & & & & B & 0 & 1 & 3 & + & & & \\
\hline \multirow[t]{4}{*}{ NTC6915 } & 30 & $2 / 92$ & 1 & A & 2 & & & + & & & \\
\hline & & & & B & 3 & & & +++ & & & \\
\hline & & & 2 & A & 2 & & & + & & & \\
\hline & & & & B & 3 & & & +++ & & & \\
\hline \multirow[t]{4}{*}{ NTC70173 } & $\begin{array}{ll}3 & 15\end{array}$ & $2 / 91$ & 1 & $\mathrm{~A}$ & 2 & & & + & & & \\
\hline & & & & B & 0 & & & + & ++ & & \\
\hline & & & 2 & A & 0 & & & + & & & \\
\hline & & & & B & 1 & & & + & & & \\
\hline \multirow[t]{2}{*}{ NTCStan } & $14^{r}$ & $11 / 90$ & 1 & $\mathrm{~A}$ & 3 & & & ++ & & & \\
\hline & & & & B & 3 & & & ++ & & & \\
\hline
\end{tabular}

${ }^{2}$ Position $\mathrm{A}=$ apical leaves, $\mathrm{B}=$ basal leaves, $\mathrm{M}=$ leaves from the middle of the branch.

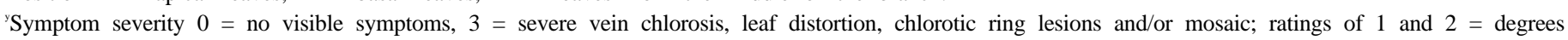

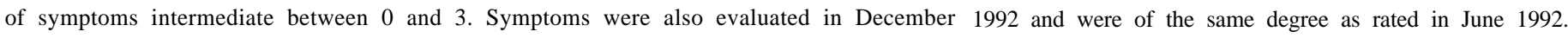
${ }^{x}$ TAS ELISA positives were at least $2.5 \times$ uninoculated NTCs.

"Apical and basal leaves bulked.

Blank spaces indicate no data collected.

"Analysis conducted on regrowth from the base of the dead branch.

'No new growth from which to sample young leaves.

shoot arising from a healthy GF305 peach bud grafted onto plum plant February 1992.

'Plant 14, untransformed 'Stanley' grafted onto peach rootstock, produced only one branch.

leaves of inoculated plants (Table 2).

During the course of our evaluations, all but one of the inoculated plants (EF1 \#24) were either symptomatic, ELISA positive, or both. No symptoms were observed on any part of plant \#24 during the course of testing between February 1992 and April 1993. During this period, all ELISA assays were negative (Table 2).

The GF305 inoculum branch on this plant was at least $15 \mathrm{~cm}$ long, expressed PPV symptoms, and was strongly ELISA positive. The RT-PCR assay of December 1992 was the only indication of the presence of PPV in this plant (Table 2, Fig. 3). This assay also suggested a low virus titer in EF1 \#24, since compared with inoculated transgenic EF1 \#8, and infected GF305, the amplified band in the EF1 \#24 samples was very weak. The strong growth of the GF305 inoculum source suggested that plant \#24 should have had a high virus titer and good symptomatology, but this was not observed.
Plant EF1-24 and several other plants were evaluated further during the period December 1992 to October 1994. Clones ST1-4, EF1-8, EF1-23, and EF2-11 continued to show strong symptoms. In May 1993, it appeared that some basal leaves of plant \#24 were showing chlorotic spots resembling PPV symptoms. At this time it was decided to further assay this plant for infection by grafting into it multiple buds of healthy GF305 as additional infection indicators. In September 1993, the shoots which grew out of these buds, and leaves from all branches of plant \#24 were tested through ELISA and RT-PCR for the presence of PPV and by PCR for the presence of the PRVCP transgene. The results of these assays are illustrated in Fig. 4. All samples were PCR-positive for the PRVCP gene. ELISA assays for PPV infection were positive for only two of the 20 samples. These two were from the original infected GF305 inoculum source (sample 15, Fig. 4) and from plum leaves 


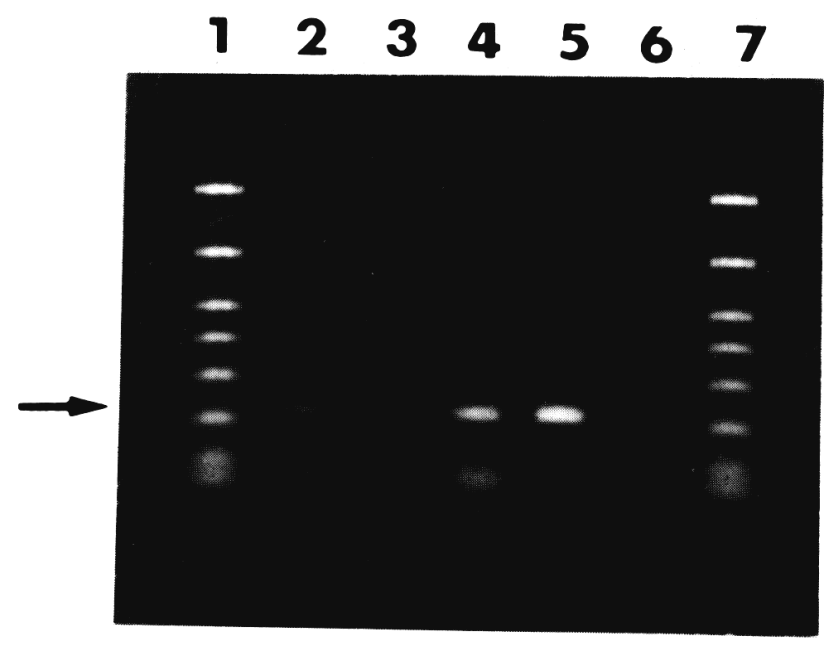

Fig. 3. RTPCR detection of the 3' noncoding region of PPV in transgenic plum plants (December 1992). The arrow indicates the location of the 220-bp band that corresponds to the size of the PPV-specific product. Samples were loaded as follows: lanes 1 and 7, BioLow DNA molecular weight markers of 1000,700, 500, 400, 300, 200,100, and $50 \mathrm{bp}$; lane 2, transgenic EF1 plant \#24 branch 1; lane 3, transgenic EFI plant \#24 branch 2; lane 4, transgenic EF1 plant \#8 branch 1; lane 5, GF305 indicator bud on transgenic EF1 plant \#24; and lane 6, transgenic noninfected EFI plant \#4 control. The PPV was amplified in transgenic challenged plants, but not in the transgenic noninfected control

on a basal branch (sample 8). PPV-RT-PCR assays confirmed that the original GF305 inoculum source was infected along with plum sample 8. This assay further indicated that GF30.5 sample 12, which was on the same branch as infected plum sample 8, was infected, as was plum sample 13 on a basal branch close to the original inoculation site. Beyond these foci of infection, which were confined to the branches of the plant basal to the inoculum, the infection had not spread. In fact, a demarcation of virus spread was clearly seen between the infected basal leaf sample 13 and the healthy apical leaf sample 14 , the two being separated by only a few $\mathrm{cm}$, and again, between the infected basal leaf sample 8 and the healthy apical leaf sample 9. It should also be noted that a healthy GF305 (sample 7) which had been bud-grafted in May 1993 onto the same branch that had an infected lateral branch (sample 13), was still uninfected after 4 months of summer growth. It appeared that infection in plant \#24 was limited to branches basal to the original site of inoculation even after 19 months. The original RTPCR-positive sample from plant \#24 (Table 2) was a composite of leaves collected at random throughout the plant which included both infected basal leaves and \&infected leaves. Finally, in October 1994, 32 months after inoculation, all branches of plant EF1.24 began to show distinct PPV symptoms on basal leaves. The presence of PPV throughout the plant was further verified by positive ELISA and RT-PCR assays (Table 2).

\section{Discussion}

The plants in our tests were placed under a severe infection pressure through graft inoculation. Infected GF305 shoots were growing on 11 of the 32 test plants. Other plants had live GF305 buds, but no shoot growth from these buds. This grafting provided a constant source of PPV inoculum compared with occasional aphid transmission, which would be expected in the field. Besides providing a severe challenge, grafting was used instead of insect transmis- sion because it was reliable, convenient, and because insect transmission tests were restricted to midwinter months by the APHIS permit under which the study was conducted. PPV infection was allowed to proceed for at least 10, and up to 32 months, allowing ample time for infection to take place. With a combination of multiple branch sampling per plant, separate evaluation of young and old leaves, the use of an in planta indicator plant, visual rating of symptoms, ELISA and RT-PCR, we were able to conclude that all plants were infected with PPV. Infection was most rapid for those plants inoculated in late winter (February) with most plants showing good symptom expression and positive ELISA results within 4 months. It took up to 10 months to verify infection of some plants when inoculated in November Most PRVCP transgenic plants did not appear to be more resistant to PPV than the non-transgenic controls. We could find individual transgenic plants with milder symptoms than particular non-transgenie controls, but the inverse could also be found. The development of additional PRVCP transgenic plum lines would be useful to further study potential levels of protection with PRVCP.

For 10 months, one plant (\#24) of transgenic clone EF1 exhibited a high level of protection without symptoms or ELISApositive reactions. By 19 months, positive ELISA and RT-PCR results were obtained on a branchbasal to the inoculation site (the inoculum branch was still actively growing on this plant). Only after 32 months did clear symptoms begin to be expressed throughout the plant along with positive ELISA and RT-PCR assays. While this clonally propagated plant of transgenic clone EF1 appeared to be able to limit PPV infection for many months, eight other clonally propagated plants, all propagated from the same original EF1 transformant, showed mild to severe symptoms of PPV and positive ELISA values much earlier, within 4-7 months postinoculation (Table 1). The reason for this is unclear. Normally it is assumed that a transgenic line would show similar levels of protection in all of its vegetative propagules, barring a low incidence of mutation (e.g., loss of the transferred gene or gene duplication during mitosis). The possibility of chimerism was evaluated through GUS assays in which all EF1 clones were GUS positive. Plant EF1 \#23 which showed symptoms a short time after inoculation showed the same Southern hybridization pattern as EF1-24 (data not presented), again suggesting that EF1 plants were not different in regard to the presence or structure of the transgenes. Smith et al. (1994) found variability in disease reaction in doubled haploid tobacco plants containing a transgene which produced an untranslatable potato virus Y-CP mRNA. These plants were genotypically identical, with transgenes in identical chromosome sites. While the reason for this variability was unclear, the authors suggested that some undefined host component in these transgenic plants was partially responsible. They further suggested that this phenomenon may be at least in part a result of methylation of transgene sequences. Our results with plum also demonstrate a within-clone variability and we cannot explain the source of variability. As indicated by Smith et al. (1994) such plants may provide a system for the study of poorly understood modifier genes.

Virus protection in this study could have been affected by the heterologous nature of the $\mathrm{CP}$. Heterologous protection has been shown to be less effective than protection by homologous virus $\mathrm{CP}$ (Ling et al., 1991; Namba et al., 1992). We have developed plum plants carrying the PPVCP (Scorza et al., 1994b). These are being tested for resistance to PPV and compared with PRVCP transgenic plums.

Besides the direct effects of $\mathrm{CP}$ on virus expression, other factors such as the environment and unevenness of virus distribution in woody plants (Adams, 1978; Bitterlin et al., 1984, 1988; 


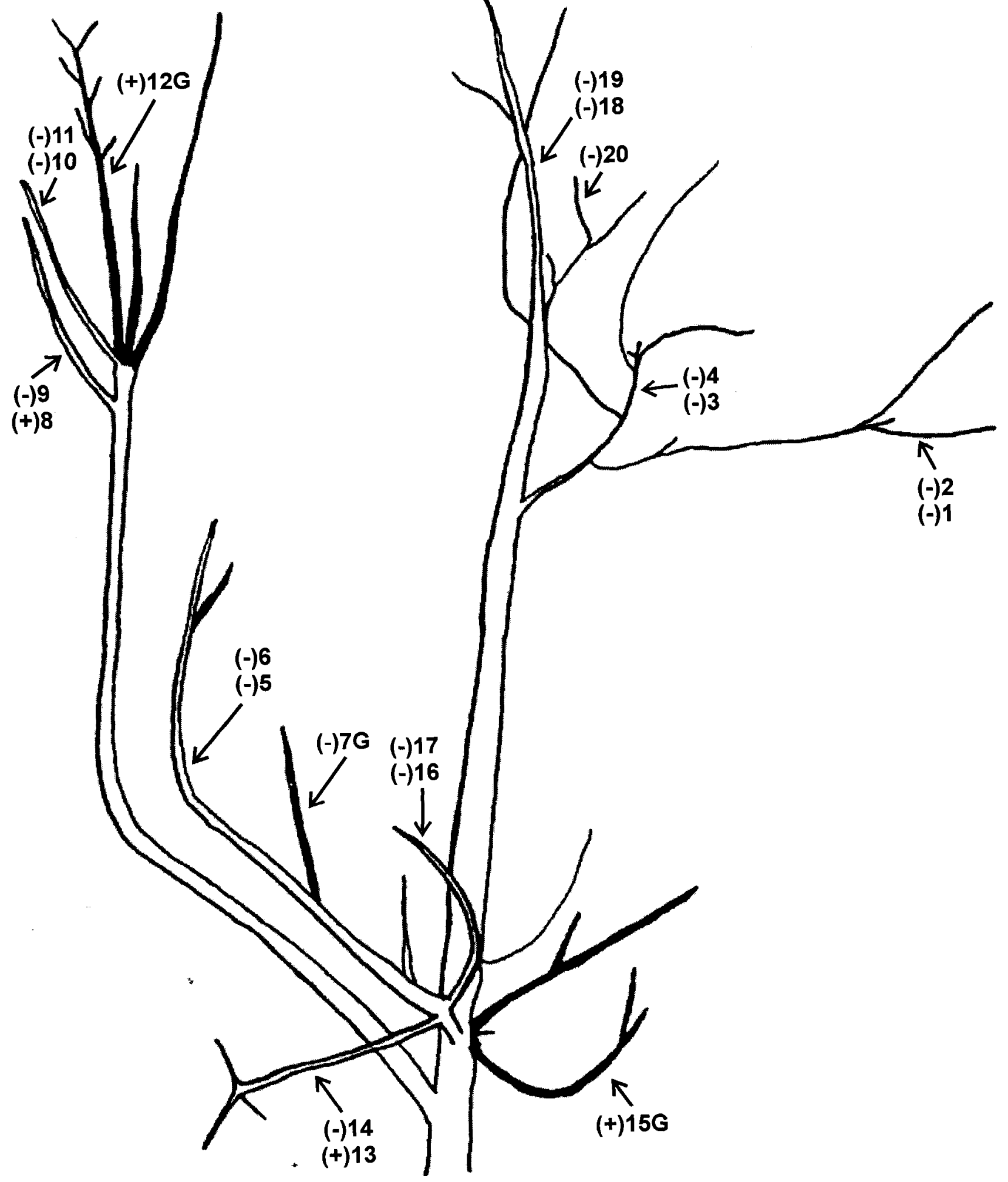

Fig. 4. Diagram of transgenic plum plant \#24, September 1993.19 months postinoculation, illustrating sampling and results of RTPCR analysis for the presence of PPV. Numbers indicate leaf samples. Where two sample numbers appear together the lower number indicates a sample of basal leaves, the higher number, apical leaves. Numbers appearing singly are generally apical leaf samples. Positive (+) and negative (-) designations indicate the presence or absence of PPV, respectively, in the leaves sampled. Sample numbers followed by the letter "G" were obtained from GF305 peach leaves produced on branches grown from buds that had been previously grafted onto the plum plant. These GF305 peach branches are darkened. Sample 15G was the original PPV-infected GF305 inoculum. Samples $15 \mathrm{G}$ and 8 were also ELISA positive for PPV. All plum samples were PCR positive for the presence of the PRVCP transgene. 
Desvignes et al., 1992; Dunez and Sutic, 1988) most likely affected levels of protection. The differences in symptom expression and ELISA reaction between branches within individual plants noted in this study (Table 2) suggest unevenness of virus distribution. Environment also appears to have affected virus titer as indicated by ELISA assays. Absorbances during the early summer of 1991 were generally higher than in the winter. Furthermore, $40 \%$ of the plants that were ELISA positive in the summer were negative in the winter. This suggests that virus titers are low during periods of slow growth or that CP-mediated protection is affected by environment and the plant's reaction to environment vis-a-vis dormancy, spring growth flushes, etc. In our study supplemental lighting and warm temperatures allowed plants to grow continuously throughout the years of the trial. No environmental chamber was available to induce a cycle of dormancy. A period of dormancy could have affected the progress of the disease. Desvignes et al. (1992) suggested that a 2-month exposure to 5C may hasten symptom expression and ELISA-positive reactions of woody indicator plants infected with apple proliferation. Certainly, cold temperatureinduced dormancy will be a factor that will affect disease development in the field.

One of the chief advantages of gene transfer in vegetatively propagated crops would be the ability to carry the transgene, unaltered, through many cycles of vegetative propagation (Scorza, 1991). Some fruit tree cultivars have been maintained and dispersed by humans for over 100 years through vegetative propagation (Whealy, 1989). Instability in expression of a transgene through vegetative propagation would limit the usefulness of gene transfer for the improvement of these crops. Beyond the question of stability of transgene expression through vegetative propagation and questions of seasonal effects, the long-term stability of transgene expression over a period of 10-20 years in an individual tree under repeated natural inoculation must be considered. To date most studies of $\mathrm{CP}$-mediated virus protection have been undertaken on annual seed-propagated crops. It has only been relatively recently that transformation with $\mathrm{CP}$ genes has been reported in woody perennials (Laimer da Camara machado et al., 1992, Scorza et al., 1994b). The current report extends our knowledge of CP-mediated protection into a woody perennial species.

While our initial results suggest that the heterologous PRVCP may not provide adequate protection against PPV in plum, at the same time, it is clear that many questions remain to be answered before we can critically determine the usefulness of this strategy. Some of these questions concern the stability of transgene expression following vegetative propagation, transgene stability over the long life of an individual tree and the longer life of a clone, transgene expression in various organs of large trees, the effects of dormancy and seasonal growth flushes, and the effects of virus strain, and differences between heterologous and homologous protection.

\section{Literature Cited}

Abel, P.P., R.S. Nelson, S, B. De, N. Hoffmann, S.G. Rogers, R.T. Fraley, and R.N. Beachy. 1986. Delay of disease development in transgenic plants that express the tobacco mosaic virus coat protein gene. Science 232:738-743.

Adams, A.N. 1978. The detection of plum pox virus in Prunus species by enzyme linked immunosorbent assay (ELISA). Ann. Appl. Biol. 90:215221.

Atanasoff, D. 1932. Plum pox-A new virus disease. Annals of the Univ. Sofia, Fac. of Agr. and Silvicult. 11:49-69.

Bauman, G. 1965. Die ubertragung der virosentriebsucht auf apfelsanitinge in gewachshaus. Nachrichtenbl. Dt. Pflanzenschultzd. (Braunschweig)
157:73-75

Beachy, R.N., S. Loesch-Fires, and N.E. Turner. 1990. Coat proteinmediated resistance against virus protection. Annu. Rev. Phytopathol. 28:451-474.

Bitterlin, M.W., D. Gonsalves, and J. Cummins. 1984. Irregular distribution of tomato ringspot virus in apple trees. Plant Dis. 68:567-571.

Bitterlin, M.W., D. Gonsalves, and J.G. Barrat. 1988. Distribution of tomato ringspot virus in peach trees: Implications for viral detection. Plant Dis. 72:59-63.

Christoff, A. 1958. Die obstvirosen in Bulgarien. Phytopathol. Z. 31:381436.

Clark, M.F. and A.N. Adams. 1977. Characteristics of the microplate method of enzyme-linked immunosorbent assay for the detection of plant viruses. J. Gen. Virol. 34:475-483.

Cropley, R. 1968. The identification of plum pox (Sharka) virus in England. Plant Pathol. 17:66-70.

Cummins, J.N. 1991. List 35, register of new fruit and nut varieties. HortScience 26:951-986.

Desvignes, J.C., R. Boye, D. Comaggia, and N. Grasseau. 1992. Quick detection of the principal apple and pear virus diseases. Acta Hort. 309:377-384.

Dunez, J. and D. Sutic. 1988. Plum pox virus (PPV). In: Smith I.M., Dunez J., Lelliot R.A., Phillips D.H., and Archer S.A. (eds.). European handbook of plant diseases. p. 44-46.Blackwell Sci. Publ.

Fitch, M.M.M., R.M. Manshardt, D. Gonsalves, J.L. Slightom, and J.C. Sanford. 1990. Stable transformation of papaya via microprojectile bombardment. Plant Cell Rpt. 9:189-194.

Fitch, M.M.M., R.M. Manshardt, D. Gonsalves, J.L. Slightom, and J.C. Sanford. 1992. Virus resistant papaya plants derived from tissues bombarded with the coat protein gene of papaya ringspot virus. Biol Technology 10: 14661472.

Hadidi, A. and L. Levy. 1994. Accurate identification of plum pox virus and its differentiation from Prunus latent potyvirus in Prunus. EPPO Bul. 24:633-643.

Jefferson, R.A. 1987. Assaying chimeric genes in plants: The GUS gene fusion system. Plant Mol. Biol. Rpt. 5:387-405.

Jordan, R. and J. Hammond. 1991. Comparison and differentiation of potyvirus isolates and identification of strain-, virus-, subgroup-specific and potyvirus group-common epitopes using monoclonal antibodies. J. Gen. Virol. 72:25-36.

Kassanis, B. and D. Sutic. 1965. Some results of recent investigations of Sharka (plum pox) virus disease. Zast. Bilja 16:335-340.

Kegler, H., H.B. Schmidt, and D. Trifonov. 1964. Identitizierung, nachweis und eigenschaften des scharka-virus der pflaume (plum pox virus). Phytopathol. Z. 50:97-111.

Kunze, L., and H. Krczal. 1971. Transmission of Sharka virus by aphids. Proc. 8th Eur. Symp. Fruit Tree Virus Dis. p. 255-260.

Laimer da Camara Machado, M., A. da Camara Machado, V. Hanzer, H. Weiss, F. Regner, H. Steinkellner, D. Mattanovich, R. Plail, E. Knapp, B. Kalthoff, and H. Katinger. 1992. Regeneration of transgenic plants of Prunus armeniaca containing the coat protein gene of plum pox virus. Plant Cell Rpt. 11:25-29.

Levy, L. and A. Hadidi. 1994. A simple and rapid method for processing tissue infected with plum pox potyvirus for use with specific 3 ' noncoding region RT-PCR assays. EPPO Bul. 24:595-604.

Ling, K.S., S. Namba, C. Gonsalves, J.L. Slightom, and D. Gonsalves 1991. Protection against detrimental effects of potyvirus infection in transgenic tobacco plants expressing the papaya ringspot virus coat protein gene. Bio/Technology 9:752-758.

Llacer, G., M. Cambra, A. Lavina, and J. Arambur. 1986. Investigations on plum pox (Sharka) virus in Spain. Acta Hort. 193:155-159.

Louro, D. and L.M. Corvo. 1986. Occurrence of Sharka in Portugal. Acta Hort. 193:183-186.

Maiti, I.B., J.F. Murphy, J.G. Shaw, and A.G. Hunt. 1993. Plants that express a potyvims proteinase gene are resistant to virus infection. Proc. Natl. Acad. Sci. USA 90:6110-6114.

Mante, S., R. Scorza, and J.M. Cordts. 1989. Plant regeneration from cotyledons of Prunus persica, Prunus domestica and Prunus cerasus. Plant Cell Tissue and Organ Cult. 19:1-11. 
Mante, S., P.H. Morgens, R. Scorza, J.M. Cordts, and A.M. Callahan. 1991. Agrobacterium-mediated transformation of plum (Prunus domestica L.) hypocotyl slices and regeneration of transgenic plants. Bio/ Technology 9:853-857.

Mazyad, H.M., M.K. Nakhla, and A. Abo-Elea,1992. Occurrence of plum pox (Sharka) virus on stone fruit trees in Egypt. Acta Hort. 309:119-124

McKinney, H.H. 1929. Mosaic disease in the Canary Islands, West Africa, and Gibraltar. J. Agr. Res. 39557-558.

Murashige, T. and F. Skoog. 1962. A revised medium for rapid growth and bioassays with tobacco tissue cultures. Physiol. Plant. 15:473-497.

Namba, S., K. Ling, C. Gonsalves, J.L. Slightom, and D. Gonsalves. 1992. Protection of transgenic plants expressing the coat protein gene of watermelon mosaic virus II or zucchini yellow mosaic virus against six potyviruses. Phytopathology 82:940-946.

Nemeth, M. 1986. Virus, mycoplasma, and rickettsia diseases of fruit trees. Martinus Nijhoff Publ., Dordrecht.

Refatti, E., R. Osler, N. Loi, and E. Vindimian. 1985. Sharka disease in a plum area of Trento province, Italy. Riv. Pathol. Veg. 21:41-49.

Roy, A.S. and I.M. Smith. 1994. Plum pox situation in Europe. EPPO Bul. 24:1515-523.

Sanford, J.C. and S.J. Johnston. 1985. The concept of parasite-derived resistance-Deriving resistance genes from the parasite's own genome. J. Theoretical Biol. 113:395-405.

Scorza, R. 1991. Gene transfer for the genetic improvement of perennial fruit and nut crops. HortScience 26:1033-1035.

Scorza, R., J.M. Cordts, S. Mante, D. Gonsalves, V.D. Damsteegt, L.M. Yepes, and J.L. Slightom. 199 1. Agrobacterium-mediated transformation of plum (Prunus domestica L.) with the coat protein gene of papaya ringspot virus. 3rd Intl. Congr. Plant Mol. Biol., 6-11 October 1991, Tucson, Ariz. Abstr. 1167.

Scorza, R., T.W. Zimmerman, J.M. Cordts, and K.J. Footen. 1994a. Horticultural characteristics of transgenic tobacco expressing the rolC gene from Agrobacterium rhizogenes. J. Amer. Soc. Hort. Sci. 119: 1091
1098

Scorza, R., M. Ravelonando, A.M. Callahan, J.M. Cordts, M. Fuchs, J. Dunez, and D. Gonsalves. 1994b. Transgenic plums (Prunus domestica L.) express the plum pox virus coat protein gene. Plant Cell Rpt. 14: 1822.

Scorza, R., J.M. Cordts, D.W. Ramming, and R.L. Emershad. 1995. Transformation of grape (Vitis vinifera L.) zygotic-derived somatic embryos and regeneration of transgenic plants. Plant Cell Rpt. 14:589592.

Slightom, J.L. 1991. Custom polymerase-chain-reaction engineering of a plant expression vector. Gene 100:252-255.

Slightom, J.L., R.F. Drong, L.C. Sieu, and P.P. Chee. 1991. Custom polymerase chain reaction engineering plant expression vectors and genes for plant expression, p. 1-55. In: S.B. Gelvin, R.A. Schilperoot, and D.P.S. Verma (eds.). Plant molecular biology manual B16. Kluwer Academic Pub., Dordrecht, The Netherlands.

Smith, H.A., S.L. Swaney, T.D. Parks, E.A. Wernsman, and W.G. Dougherty. 1994. Transgenic plant virus resistance mediated by untranslatable sense RNAs: Expression, regulation, and fate of nonessential RNAs. Plant Cell 6:1441-1453.

Stark, D.M. and R.N. Beachy. 1989. Protection against potyvirus infection in transgenic plants: Evidence for broad spectrum resistance. Vio Technology 7: 1257-1262.

Sutic, D., and T.S. Pine. 1968: Sharka (plum pox) disease. Plant Dis. Rpt. 52:253-256

Trifonov, D. 1974. Susceptibility to the plum pox virus of twelve varieties of the cultivar Kjustendilska sinya silva. Publishing House Bulgarian Acad. Sci. Virol., Sofia, Bulgaria. p. 131-138.

Whealy, K. 1989. Fruit, berry and nut inventory. Seed Saver Publ., Decorah, Iowa.

Yang, X., A. Hadidi, and SM. Garnsey. 1992. Enzymatic cDNA amplification of citrus exocortis and cachexia viroids from infected citrus hosts. Phytopathology. 82:279-285. 